\title{
Range extension of the sesarmid crab Clistocoeloma villosum along the eastern Pacific coast of the Izu Peninsula, Japan
}

Takeshi Yuhara ${ }^{1 *}$, Hiroyuki Yokooka² and Masanori Taru ${ }^{3}$

\begin{abstract}
Background: The Pacific coastline along the southern Izu Peninsula, Japan, is strongly influenced by warm tropical waters of the Kuroshio Current. A new easternmost record of the near-threatened sesarmid crab Clistocoeloma villosum is reported from the southern part of Izu Peninsula.

Methods: The present study was conducted in August 2014 and February 2015, on tidal flats in the mouth of the Aono River, draining the southern part of Izu Peninsula. Crabs were collected by hand on the tidal flat substrate, under cobble stones and on the periphery of associated mangrove forests.

Results and conclusion: Body sizes and morphological characteristics closely matched existing descriptions of $C$. villosum, the distribution range having been extended ca. $350 \mathrm{~km}$ eastward from the Kii Peninsula (traditional eastern boundary of the species), suggesting broad northeastwardly directed planktonic larval transport by the warm Kuroshio Current along the Pacific coast of Japan. The survival and settlement of larvae of this southern species along the southern coast of the Izu Peninsula, is evidence of the suitability of the small gravel dominated tidal flats in the region as habitat for the species.
\end{abstract}

Keywords: Clistocoeloma villosum, Brachyura, Near-threatened species, New record, Izu Peninsula, Kuroshio current, Larval dispersion

\section{Background}

The coastline of southern Izu Peninsula, southeastern Honshu Island, Japan is strongly influenced by the Kuroshio Current, which carries warm tropical waters in a northeastwardly direction (Yamano et al., 2011). Although the short steeply graded rivers characteristic of the peninsula largely restrict the formation of tidal flats at the river mouths, the Aono River mouth is characterized by very small tidal flats, including salt marshes and semi-mangrove forests. General investigations of benthic macro-invertebrates on the tidal flats have included accounts of a number of crab species (Tanaka et al., 2004; Ito, 2014; Yokooka et al., 2015), as well as snails (Nishiwaki et al., 1991; Murase \& Yuhara, 2011). However, detailed investigations of the tidal flats and associated semi-mangrove areas have not yet been undertaken.

\footnotetext{
* Correspondence: yugo88@nifty.com

${ }^{1}$ Tohoku University Graduate School of Life Science, 6-3 Aoba, Aramaki,

Aoba-ku, Sendai, Miyagi 980-8578, Japan

Full list of author information is available at the end of the article
}

The present report details the first records of the sesarmid crab Clistocoeloma villosum (A. Milne Edwards, 1869) on the tidal flats and in the semimangrove forest area of the Aono River mouth, southern Izu Peninsula. Previously, the distribution range of this crab in Japan had been recognized as between the Ryukyu Islands and Kii Peninsula, southern Honshu Island (see Karasawa et al., 2006), approximately $350 \mathrm{~km}$ distant from Izu Peninsula.

\section{Methods}

The present study was conducted in August 2014 and February 2015. Clistocoeloma villosum was monitored along the Aono River $\left(34^{\circ} 38^{\prime} 06^{\prime \prime} \mathrm{N}, 138^{\circ} 53^{\prime} 11^{\prime \prime}\right.$ E) at Minami-Izu Town, Izu Peninsula, Shizuoka, Japan (Fig. 1), the intertidal zone habitat of the river mouth being characterized by mud flats, gravels, cobble stones, oyster beds and salt marshes. Plants included the common reed (Phragmites australis), semi-mangrove plants, such as Hibiscus hamabo (Nakanishi, 2001), and the 


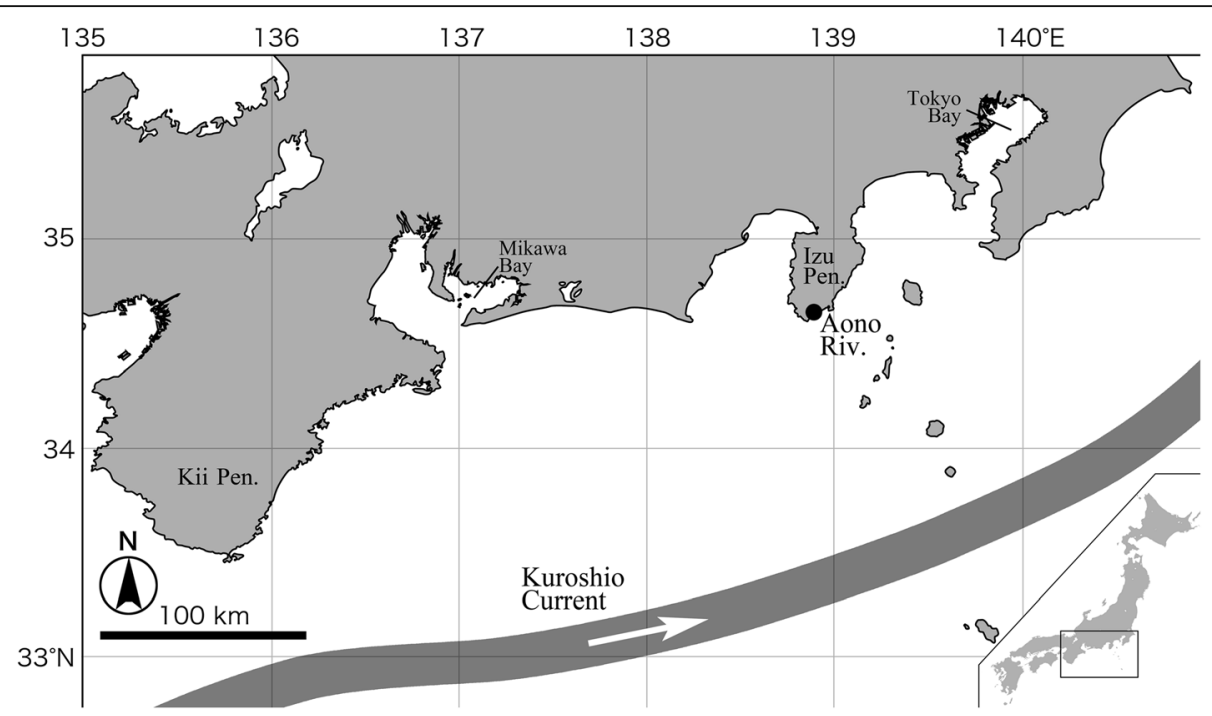

Fig. 1 Map showing the Kuroshio Current off southeastern Japan and the Izu Peninsula, and the sampling location

mangrove Kandelia obovata, introduced from Iriomote Island, Japan in 1959 (Masuda, 1999).

Brachyuran crabs were collected by hand from the mud flat surface, under gravels and cobble stones around the mangrove forest edges. All crabs collected were stored in $70 \%$ ethanol and representative specimens deposited in the Osaka Museum of Natural History. Familial and generic classification followed the guidelines proposed by de Grave et al. (2009). Descriptions and specific keys used for identifying C. villosum included Tesch (1917), Crosnier (1965), Nomoto et al. (1999), Komai et al. (2004) and Lee et al. (2010).

\section{Results}

\section{Systematics}

Order DECAPODA (Latreille, 1802)

Infraorder BRACHYURA (Linnaeus, 1758)

Family SESARMIDAE (Dana, 1851)

Genus Clistocoeloma (A. Milne Edwards, 1873)

Clistocoeloma villosum (A. Milne Edwards, 1869) Fig. 2

Sesarma villosum A. Milne-Edwards, 1869:31.

Sesarma (Holometopus) villosa: Tesch, 1917:208, pl. 17, Fig. 2.

Sesarma (Holometopus) villosum: Crosnier, 1965:55, figs $75,76,77 \mathrm{a}, 78$.

Chiromantes villosum: Nomoto et al., 1999:9, pls. 1-6; Kishino et al., 2001:17, pl. 2,2; Shokita et al., 2002:78, photo 4A-1.

Clisotocoeloma villosum: Davie, 2002:221; Komai et al., 2004:39, fig. 3; Lee et al., 2010:180, Fig. 1; Maenosono \& Saeki, 2016:5, Fig. 2d.

Material examined (all from Aono River mouth, southern Izu Peninsula, Shizuoka, Japan): OMNHAr10119, 1 male, CW: 11.6 mm, CL: 9.6 mm, 1 female,
CW: $10.3 \mathrm{~mm}$, CL: $8.4 \mathrm{~mm}$, upper intertidal, mud bottom under cobble stone, coll, T. Yuhara, 31 August 2014; OMNH-Ar10120, 1 male, CW: $15.1 \mathrm{~mm}$, CL: $12.7 \mathrm{~mm}, 1$ female, CW: $9.1 \mathrm{~mm}$, CL: $7.8 \mathrm{~mm}$, upper intertidal, mud bottom under cobble stone, coll, $\mathrm{T}$. Yuhara, 7 February 2015.

\section{Diagnosis}

Carapace rectangular (Fig. 2a), greatest width across middle, about 1.2 times length; dorsal surface with numerous very short stiff setae, often in small groups; lateral margins slightly sinuous, anterior part slightly convex, lined with short stiff setae similar to those on dorsal surface; frontal margin moderately deflexed with faint median notch. No trace of epibranchial tooth. Antennule and antenna contiguous. Basal antennular segment subrectagular. Antenna set oblique; flagellum relatively long, extending into orbit. Third maxilliped with well development flagellum on exopond.

Chelipeds of male (Fig. 2b) and female (Fig. 2c) subequal; palm of male with 1 lined, partially pectinated ridge along entire length of dorsal surface, comprising a few small granules and 20-38 small to large corneous teeth; inner surface comprising a row of small tubercles adjacent to dorsal margin (Fig. 2d); palms of females with a few small granules only on dorsal surface; upper border of dactylus of male bearing ca. 30 rectangular tubercles in a line toward lower tip (Fig. 2e), that of female bearing 15 small tubercles in a line becoming base toward middle of dactylus.

Ambulatory legs (Fig. 2f) (second to fifth pereopods) moderately short, third and fourth legs of similar length, longer than second and fifth, covered with short stiff setae; merus broad, terminal of anterior upper margin 


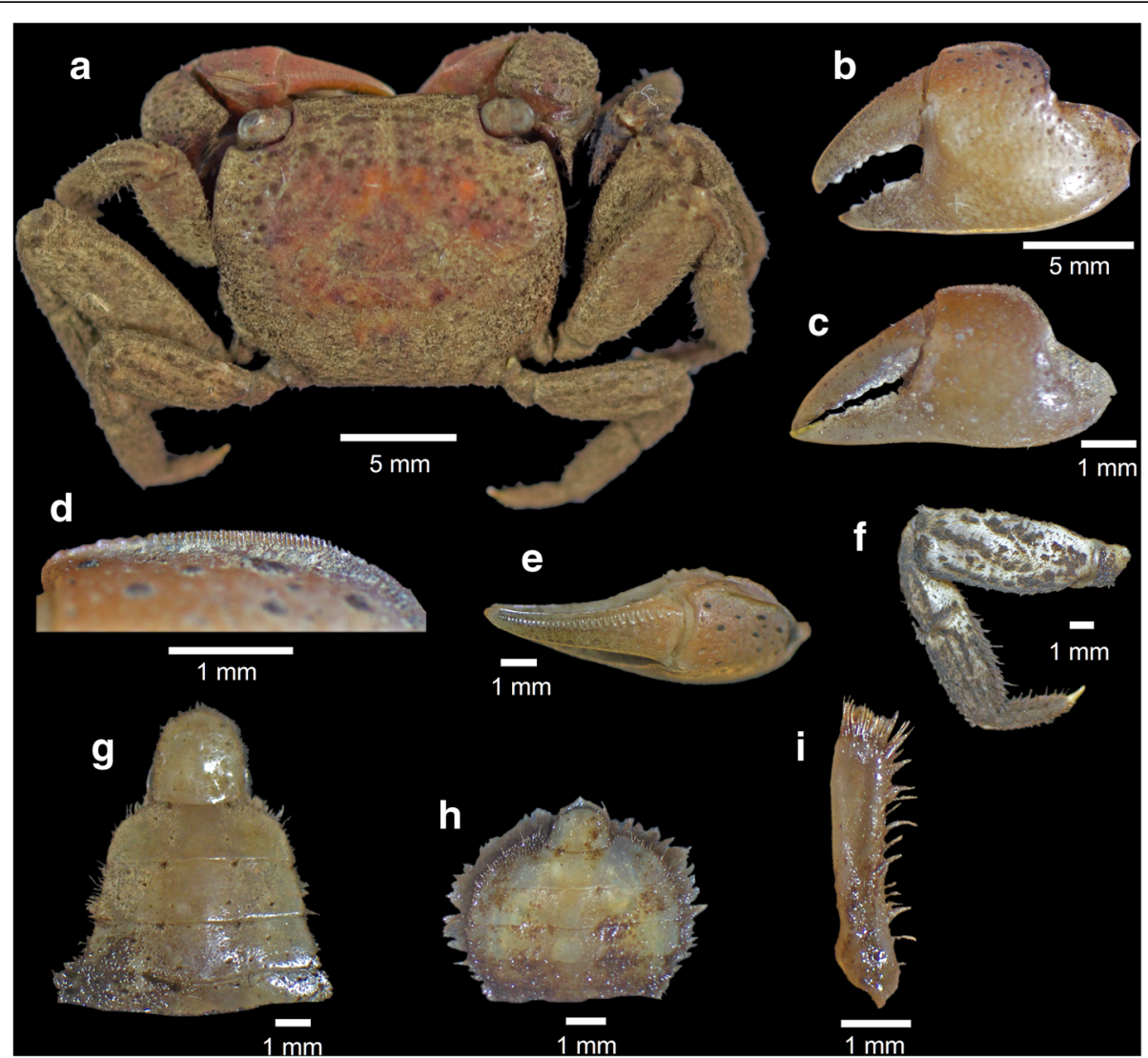

Fig. 2 Clistocoeloma villosum (A. Milne Edwards, 1869), male, CW 15.1 mm, CL 12.7 mm, female, CW 9.1 mm, CL 7.8 mm (OMNH-Ar10120), Aono River. a morphogy of dorsal view of carapace of male; $\mathbf{b}$ left cheliped of male, outer view; $\mathbf{c}$ left cheliped of female, outer view; $\mathbf{d}$ inner dorsal margin of left palm of male, showing crest, outer view; e left cheliped of male, dorsal view; $\mathbf{f}$ left fifth perepod of male, dorsal view; $\mathbf{g}$ abdomen of male; $\mathbf{h}$ abdomen of female; $\mathbf{i}$ left first pleopod, outer view

without corneous spinules; propodus and dactylus covered with numerous short stiff setae, upper and lower margins lined with rows of longish setae, dactylus terminating in corneous claw, tip without hairs.

Abdomen of male (Fig. 2g) wide, narrowest at base of telson, covered with short setae; fifth and sixth abdominal somites of similar length; telson slightly longer than basal width. Abdomen of female (Fig. 2h) with telson evenly rounded, as long as basal width and longer than mid-line length of sixth abdominal somite. The anterior of sixth abdominal somite gently sunk and put the telson in it.

First gonopod (Fig. 2i) stout, nearly straight; terminal process short, with shallow notch distally.

Crosnier (1965) and Lee et al. (2010) reported that the male chelipeds in this species have 15-16 corneous teeth on the dorsal surface of the palm, whereas Tesch (1917) and Komai et al. (2004) reported males with 20-30 teeth. The present male specimens had 20-38 such teeth, the number varying with body size.

The collected specimens corresponded closely to the descriptions of Sesarma (Holometopus) villosa provided by Tesch (1917), Sesarma (Holometomus) villosum, provided by Crosnier (1965), Chiromantes villosum provided by Nomoto et al. (1999), and Clistocoeloma villosa, provided by Komai et al. (2004) and Lee et al. (2010).

\section{Coloration}

Generally in life, carapace muddy colour; palm of cheliped purplish.

\section{Distribution}

Clistocoeloma villosum is widely distributed in the IndoPacific Ocean, including Madagascar, Aceh, Sumatra, New Guinea, Queensland, Australia, Caroline Islands, Samoa Islands and Korea (Jejudo Island) (Tesch, 1917; Crosnier, 1965; Komai et al., 2004; Lee et al., 2010). Previous records along Japanese coastal regions include the central and southern Ryukyu Islands (Miyako, Iriomote, Ishigaki, Okinawa and Amami-Ohshima Islands), Kyushu Island (Miyazaki Prefecture, Nagasaki Prefecture), Shikoku Island (Ehime Prefecture) and the Kii Peninsula, extending from the Honshu mainland (Wakayama Prefecture) (Kishino et al., 2001; Shokita et 
al., 2002; Komai et al., 2004; Kawakubo et al., 2005; Ministry of the Environment, 2005; Karasawa et al., 2006; Miura \& Jitsumasa, 2010; Wada, 2013; Maenosono \& Saeki, 2016).

\section{Ecological note}

Clistocoeloma villosum dwells under stones on the upper intertidal zone of tidalflats, in salt marshes and on the landward edges of semi-mangrove forests. Uncommon, except in the southern Ryukyu Islands, the species is recognized as near threatened in Japan (Japanese Association of Benthology, 2012; Ministry of the Environment, 2017). The new locality is approximately $350 \mathrm{~km}$ northeast of the Kii Peninsula, being the easternmost reported to date (see Karasawa et al., 2006).

\section{Discussion}

Although the Kii Peninsula has been the traditionallyrecognized eastern boundary of Clistocoeloma villosum, that species, along with several other crabs, i.e., Ptychognathus capillidigitatus (Yokooka et al., 2015), Macrophthalmus banzai (Yokooka \& Nomoto, 2013), Tubuca arcuata (Yuhara \& Aizawa, 2016) and Austruca lactea (Tamura \& Narita, 2013), is now established as having extended northeastward to the Izu Peninsula and Tokyo Bay, although still rare at that site. In addition, other southern-based marine invertebrates have been reported from corals (Yamano et al., 2011), nemerteans (Yamamori et al., 2013) and snails (Hayase et al., 2013).

The Kuroshio Current, which flows southwest to northeast along the Pacific coast of Japan, has enriched the communities of southern-based species on the southern Izu Peninsula area by providing aquatic environments suitable for their larvae. Planktonic crab larvae are generally dispersed over relatively long periods in the water column (Cuesta et al., 2006). Although larval development of $C$. villosum have not yet been reported, that of a closely related species [Clistocoeloma sinense (three zoeal stages; Saba, 1972, Cuesta et al., 2006)] has been observed. Because the entire brachyuran larval stage (including three zoeal stages) has been estimated as ca. 16 days (Fukuda, 1980), it is likely that a portion of juveniles originating from around the Kii Peninsula can survive transportation via coastal waters to the Izu Peninsula because of the rapid speed of the Kuroshio Current, which sometimes exceeds $2 \mathrm{~m} / \mathrm{s}$ (Teramoto, 1987). This suggests that the warm Kuroshio Current can transport planktonic larvae from the southwestern subtropical zone to the northeastern temperate zone along the Pacific coast of Japan. The larvae of southwestern-based crabs can settle and survive along the coast of the southern Izu Peninsula near the Kuroshio Current due to the favorable habitat, comprising small tidal flats with reed vegetation, gravels, cobble stones and semi-mangrove communities.

Clistocoeloma villosum dwells under stones on the upper intertidal region of tidal flats and salt marshes, as well as under leaf litter over moist soil on the landward of edges of semi-mangrove forests (Komai et al., 2004, Lee et al., 2010, Japanese Association of Benthology, 2012). However, tidal flats encompassing such environments are generally rare along the Pacific coast in approximately $250 \mathrm{~km}$ between Mikawa Bay and Tokyo Bay. Furthermore, an earlier study that revealed a salient genetic differentiation in the closely-related saltmarsh crab $C$. sinense, suggested the existence of a barrier to larval transport between these two bays (Yuhara et al., 2014). Therefore, the upper intertidal area of Aono River mouth in southern Izu Peninsula provides a vital habitat for this northeasternmost population of C. villosum.

\section{Conclusion}

The present study has clarified that the distribution range of the near-threatened sesarmid crab Clistoceloma villosum had been extended eastward from the Kii Peninsula to the Izu Peninsula. It suggests that the larvae of this crab can be transported northeastwardly along the Pacific coast of Japan by the warm Kuroshio Current in planktonic period and can be settled in the southern Izu Peninsula due to the existence of suitable habitat, comprising small tidal flats with reed vegetation, gravels, cobble stones and semi-mangrove communities.

\section{Acknowledgments}

We wish to thank the Biology Club of Shimoda High School for field assistance. We are also grateful to Ms. Mieko Takezawa for valuable advice about the Aono River. We also thank Dr. Graham S. Hardy (Whangarei, New Zealand) revised an early draft of the manuscript. We especially thank the Shizuoka Prefectural Government for cooperation to conduct this study along the semi-mangrove forest area of Aono River.

\section{Funding}

Not applicable.

Availability of data and materials

Not applicable.

Authors' contributions

TY, HY and MT collected the specimens. TY drafted the manuscript. TY and HY took the photographs of the specimens, checked the identification of the specimens and helped to improve the manuscript. MT prepared the map and helped to improve the manuscript. All authors read and approved the final manuscript.

\section{Competing interests}

The authors declare that they have no competing interests.

Consent for publication

Not applicable.

Ethics approval

Not applicable. 


\section{Publisher's Note}

Springer Nature remains neutral with regard to jurisdictional claims in published maps and institutional affiliations.

\section{Author details}

'Tohoku University Graduate School of Life Science, 6-3 Aoba, Aramaki, Aoba-ku, Sendai, Miyagi 980-8578, Japan. ${ }^{2}$ IDEA Consultants, Inc. Institute of Environmental Ecology, 1334-5 Riemon, Yaizu, Shizuoka 421-0212, Japan. ${ }^{3}$ Faculty of Sciences, Tokyo Bay Ecosystem Research Center, Toho University, Miyama 2-2-1, Funabashi, Chiba 274-8510, Japan.

Received: 18 January 2017 Accepted: 15 June 2017

Published online: 19 June 2017

\section{References}

Crosnier A. Crustaces decapodes. Grapsidae et Ocypodidae. Faune Madagascar. 1965;18:1-143.

Cuesta JA, Guerao G, Liu HC, Schubart CD. Morphology of the first zoeal stages of eleven sesarmidae (Crustacea, Brachyura, Thoracotremata) from the Indo-West pacific, with a summary of familial larval characters. Invertebr Reprod Dev. 2006;49:151-173.

De Grave S, Pentcheff ND, Ahyong ST, Chan T, Crandall KA, Dworschak PC, Felder DL, Feldmann RM, Fransen CHJM, Goulding LYD, Lemaitre R, Low MEY, Martin JW, Ng PKL, Schweitzer CE, Tan SH, Tshudy D, Wetzer R. A classification of living and fossil genera of decapod crustaceans. Raffles B Zool. 2009:21:1-109.

Fukuda Y. An attempt to estimate the length of platktonic larval period in Brachyura (1). Calanus. 1980;7:9-12

Hayase $Y$, Kageyama $Y$, Kimura S. Molluscan fauna in the mouth of Ihara river, Shizuoka city: the northward range extension of Neritimorpha. Rep Nagoya Shell Club. 2013;38:23-32.

Ito M. Distribution of the fiddler crabs Uca arcuata and Uca lactea in Shizuoka prefecture, Japan. Jpn J Bentho. 2014;69:76-84

Japanese Association of Benthology. Threatened animals of Japanese tidal flats: red data book of seashore benthos. Kanagawa: Tokai University Press; 2012

Karasawa T, Kimura S, Kuroda M, Nomoto A. Record of Clistocoeloma villosum (Crustacea, Brachyura, Sesarmidae) from the Waka river estuary in Wakayama prefecture Japan. Nanki-Seibutu. 2006;48:60-62.

Kawakubo A, Otani T, Nakahara Y, Yone H, Shimojo K, Hashiguchi K, Ito T, Kurusaki Y, Yamaguchi Y. Record of the crustacean and the mollusks from south Kujukushima isles area. Trans Nagasaki Biol Soc. 2005;60:17-27.

Kishino T, Yonezawa T, Nomoto A, Kimura S, Wada K. Twelve rare species of brachyuran crabs recorded in the brackish waters of Amami-oshima island, Kagoshima prefecture, Japan. Nanki-seibutu. 2001;43:15-22.

Komai T, Nagai T, Yogi A, Naruse T, Fujita Y, Shokita S. New records of four grapsoid crabs (Crustacea: Decapoda: Brachyura) from Japan, with notes on four rare species. Nat Hist Res. 2004;8:33-63.

Lee SY, Jung J, Kim W. A new report on sesarmid crab Clistocoeloma villosum (Crustacea: Decapoda: Brachyura) from Korea. Kor J Syst Zool. 2010;26:179-181.

Maenosono T, Saeki T. The sesarmid (Crustacea: Decapoda: Brachyura) fauna of Ishigaki-jima island, Ryukyu archipelago, Japan, with new distribution records. Fauna Ryukyuana. 2016;33:1-13.

Masuda S. Plantation of mangrove at the Aono river in Minami-Izu town, Shizuoka prefecture, Japan. Macro Rev. 1999;11:63-70.

Ministry of the Environment. The 6th national survey on the natural environment (Ehime). Biodiversity center, Nature conservation bureau. Yamanashi prefecture: Ministry of the Environment; 2005

Ministry of the Environment. The red list of the threatened marine species. http:// www.env.go.jp/press/103813.html (2017). Accessed 26 Mar 2017

Miura T, Jitsumasa T. Benthic mollusks and crustaceans recorded from the Hitotsuse river estuary, Miyazaki, Japan. B Fac Agr, Miyazaki Univ. 2010;56:29-44.

Murase A, Yuhara T. Record of an endangered gastropod, Cerithidea rhizophorarum, from estuarine habitat of Ogamo river, Southern Izu Peninsula, Central Japan. Biogeogr Soc Jpn. 2011;67:261-264.

Nakanishi H. Distribution and population of Hibiscus hamabo Siebold et Zucc. In: Studies on the vegetation of alluvial plains. (ed, The association to commemorate the retirement of Prof. Dr. Shigetoshi Okuda). Yokohama: The association of commemorate the retirement of Prof. Dr. Sigetoshi Okuda; 2001. p. $37-46$
Nishiwaki S, Hirata T, Ueda H, Tsuchiya Y, Sato T. Distribution and its factor of Clithon retropictus (Prosobranchia: Nertidae) in the rivers of Izu peninsula. B Col Med Tech Nurs Univ of Tsukuba. 1991;12:51-57.

Nomoto A, Yodo S, Kimura S, Kishino T, Sakano M, Wada K. Six rare brachyuran species of the family Grapsidae, recorded from the Kinokawa river estuary, Wakayama prefecture. Nanki-seibutu. 1999;41:5-9.

Saba M. Umore-benkeigani no koukihassei [Studies on the post-embryonic development of Clisotocoeloma merguiense de Man]. Mie-seibutsu. 1972; 22:25-29.

Shokita S, Nagai T, Fujita Y, Naruse T, Ito A, Nagamatsu T, Yamazaki T, Shinjo M, Nagata $Y$. Distribution and abundance of crustaceans in the Ohura river mangrove swamp of Okinawa island, Japan. In: A comprehensive study for mangrove ecosystem in Okinawa. Naha: Research institute for subtropics; 2002. p. 73-86

Tamura M, Narita A. New record of the fiddler crab Uca lactea, including the adult male, female and the juvenile crabs, at the mouth of Obitsu river, Kisaradu, Chiba. B Biol Soc Chiba. 2013;62:79.

Tanaka H, Shibagaki K, Ikezawa H, Kanezawa A, Wada K. Occurrence of two species of fiddler crab (Decapoda, Ocypodidae) on the tidal flat of the Aono river, Izu peninsula, Shizuoka prefecture, Japan. Jpn J Benthol. 2004;59:8-12.

Teramoto T. Kuroshio. In: Wadachi K, editor. Encyclopedia of oceanography. Tokyo: Tokyodo; 1987. p. 185.

Tesch JJ. Synopsis of the genera Sesarma, Metasesarma, Sarmatium and Clistocoeloma, with a key to the determination of the Indo-Pacific species. Zool Med. 1917;3:127-260. pls.15-17.

Wada T. Record of sesarmid crab Clistocoloma villosum from the Osaka Nankou bird sanctuary, Japan. Nat Stud. 2013;59:126-127.

Yamamori L, Hirose M, Kajihara H. Northward range extension of Baseodiscus hemprichii (Nemertea: Heteronemertea)—due to rising sea-surface temperatures? Mar Biodivers Rec. 2013;6:e100.

Yamano H, Sugihara K, Nomura K. Rapid poleward range expansion of tropical reef corals in response to rising sea surface temperatures. Geophys Res Lett. 2011:38(4):L04601. doi:10.1029/2010GL046474.

Yokooka H, Nomoto A. First record of Macrophthalmus banzai (Crustacea, Brachyura, Macrophthalmidae) in Shizuoka prefecture, Japan. Nanki-seibutu. 2013;55:137-140.

Yokooka H, Yuhara T, Tagashira R. First record of Ptychognathus capillidigitatus (Crustacea: Decapoda: Varunidae) in Shizuoka prefecture, Japan. Cancer. 2015; 24:39-45.

Yuhara T, Aizawa K. Confirming of the fiddler crab Uca arcuata at the mouth of Obitsu river in Tokyo bay. B Biol Soc Chiba. 2016;65:52-54.

Yuhara T, Kawane M, Furota T. Genetic population structure of local populations of the endangered saltmarsh sesarmid crab Clistocoeloma sinense in Japan. PLoS One. 2014:9(1):e84720. http://doi.org/10.1371/journal.pone.0084720.

\section{Submit your next manuscript to BioMed Central and we will help you at every step:}

- We accept pre-submission inquiries

- Our selector tool helps you to find the most relevant journal

- We provide round the clock customer support

- Convenient online submission

- Thorough peer review

- Inclusion in PubMed and all major indexing services

- Maximum visibility for your research

Submit your manuscript at www.biomedcentral.com/submit 